\title{
ANALISIS EFEKTIFITAS INVESTASI PROYEK TEKNOLOGI INFORMASI DENGAN MENGGUNAKAN METODE INFORMATION ECONOMICS
}

\author{
Chandra S. Rembang ${ }^{(1)}$,Ir.S.T.G. Kaunang,MT. ${ }^{(2)}$,Stanley D.S. Karouw,ST,MTI. ${ }^{(3)}$,Oktavian A. Lantang,ST. ${ }^{(4) .}$

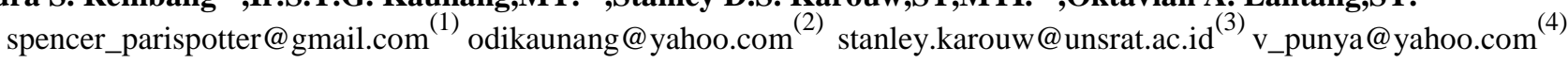 \\ Fakultas Teknik, Universitas Sam Ratulangi Manado-95115
}

\begin{abstract}
Abstrak
Investasi TI di organisasi profit merupakan hal yang wajar dewasa ini, mengingat TI telah menjadi suatu bagian gaya hidup yang tidak terpisahkan di kalangan masyarakat. Penggunaan produk TI dirasakan sangat membantu dalam hal mobilitas dan efektifitas kerja perusahaan. Investasi TI yang dilakukan seringkali muncul dengan angka besar-besaran. Sementara untuk pengukuran keuntungannya, kebanyakan organisasi profit berfokus pada keuntungan secara finansial, namun jika ditanyakan tentang manfaatnya, lebih khusus manfaat yang bersifat intangible, biasanya perusahaan tidak dapat memberikan data yang sesuai. Metode Information Economics muncul untuk menjawab kebutuhan tersebut, dengan menggabungkan perhitungan dari segi finansial dan non-finansial untuk menilai dan melakukan justifikasi terhadap investasi TI

Kata kunci: $\quad$ investasi TI, manfaat intangible, information economics
\end{abstract}

\section{Pendahuluan}

Penggunaan produk Teknologi Informasi (TI) telah menjadi suatu hal yang diprioritaskan, mengingat di tahun-tahun belakangan ini, TI telah menjadi salah satu faktor yang diperlukan dalam menunjang berbagai pekerjaan. Dalam suatu organisasi profit, penggunaan produk TI pun telah menjadi hal yang wajar dan sering dilakukan. Mereka yang tidak menggunakan produk TI dalam rangka menunjang akan kinerjanya, nampak mengalami kesulitan dalam banyak hal, mengingat banyak pekerjaan yang dulunya dilakukan dengan cara manual, telah digantikan dengan sistem komputerisasi yang terbukti memberikan kemudahan, efektifitas, dan efesiensi dari segi biaya dan tenaga kerja.

Investasi TI yang diterapkan oleh organisasi profit, jika dilihat dari besarnya nilai investasi, seringkali ditemukan nilai investasi yang mencengangkan, mengingat suatu organisasi profit benar-benar merasa perlu menggunakan produk TI tersebut. Selanjutnya ketika kita akan melihat keuntungan yang didapat dengan penggunaan produk TI tersebut, kebanyakan organisasi profit hanya memiliki data keuntungan secara finansial. Jika ditanya tentang manfaat intangible, banyak yang tidak memiliki data-data yang sesuai. Padahal, pengurangan atau pengeliminasian kontribusi manfaat intangible ini telah mengurangi nilai Return on Investment investasi TI tersebut. Dalam Tata Kelola TI, evaluasi investasi TI dan pengukuran manfaat bisnis menjadi salah satu faktor yang penting. Beberapa ahli merumuskan beberapa metode penghitungan investasi TI, yang juga memperhitungkan manfaat non-finansial.
Penggabungan pendekatan finasial dan non-finansial diharapkan akan memberikan hasil yang lebih baik dan akurat. Information Economics (IE) adalah salah satu metode penghitungan investasi TI yang menggabungkan kedua pendekatan, baik finansial maupun non-finansial untuk menilai dan melakukan justifikasi terhadap investasi TI.

Penggunaan metode $I E$ ini bertujuan untuk menilai apakah investasi TI di suatu organisasi profit efektif atau tidak, juga mengukur efektivitas investasi tersebut dan memberikan gambaran yang lebih jelas kepada organisasi profit tentang manfaat yang didapatkan dari Investasi TI dengan menggunakan Kerangka Kerja IE yang menggunakan pendekatan finansial dan nonfinansial.

\section{Landasan Teori}

A. Investasi Teknologi Informasi

Menurut Fitzpatrick, Edmund W (2005), investasi teknologi informasi merupakan total biaya dari daur hidup (life cycle) keseluruhan proyek atau bagian proyek yang melibatkan teknologi informasi, termasuk biaya operasional setelah proyek berlangsung (Post Project Operating Cost) dari system yang diimplementasikan. Investasi akan hilang eksistensinya saat investasi itu diganti atau dieliminasi dengan alasan apapun.

Secara umum, investasi TI dilakukan untuk meningkatkan produktifitas perusahaan dengan menggunakan teknologi informasi yang dapat mempercepat proses kerja serta meningkatkan efisiensi. Investasi TI banyak dilakukan oleh perusahaan untuk meningkatkan kemampuan kompetitif dari perusahaan tersebut. 
Sekarang ini untuk mengukur efektifitas dari investasi TI yang dilakukan, banyak teknik evaluasi investasi TI yang muncul untuk menjawab kebutuhan tersebut.

\section{B. Return on Investment (ROI)}

ROI adalah salah satu teknik evaluasi investasi TI. Menurut Radcliffe (1982) pendekatan $R O I$ terdiri dari sejumlah teknik pendekatan formal. Contoh yang paling sederhana dari ROI adalah payback method dimana dicoba dihitung durasi waktu yang diperlukan untuk mengembalikan investasi yang telah dialokasikan.

Menurut Ranti (2010), statistik memperlihatkan walaupun banyak perusahaan yang masih menggunakan metode ROI untuk melakukan evaluasi terhadap investasi teknologi informasinya, sebagian dari mereka merasa tidak puas dengan penggunaan metode ini.

Cantor, Murray (2012) menjabarkan beberapa tipe $R O I$ sebagai berikut:

\section{To-date ROI dan To-go ROI}

Segala jenis $R O I$ berawal dari konsep yang sama: return of investment secara umum, adalah perbandingan perubahan value terhadap biaya investasi. Dalam rumus berikut ini, $\mathrm{V}_{0}$ adalah initial value, $\mathrm{V}_{1}$ adalah value di masa selanjutnya, dan $\mathrm{I}$ adalah biaya yang dihabiskan selama dua masa tersebut.

$$
\begin{gathered}
R o I=\frac{\left(V_{1}-V_{0}\right)}{I} \\
\text { Contoh paling sederhana dalam }
\end{gathered}
$$
perhitungan $R O I$ adalah pembelian saham yang dibeli dengan suatu harga dan dijual dengan harga yang lain. Terdapat dua nilai yang mudah dimengerti dalam perhitungan ini: harga beli (pp) dan harga jual (sp), keduanya ditentukan oleh mekanisme pasar. ROI dalam contoh ini adalah perbandingan antara selisih harga dengan biaya pembelian saham, seperti dalam rumus berikut.

$$
R o I=\frac{s p-p F}{p p}
$$

Bahkan dalam kasus ini, terdapat pertanyaan-pertanyaan kunci yakni:

1. To-date; Apakah investasi yang telah saya lakukan menguntungkan?

2. To-go; Akankah saya berinvestasi dalam aset ini?

Pertanyaan pertama berkenaan dengan masa lalu. Jawaban atas pertanyaan tersebut dapat menimbulkan perubahan pada strategi investasi. Pertanyaan kedua adalah mengenai cara implementasi investasi. Untuk menjawab kedua pertanyaan tersebut dibutuhkan perhitungan $R O I$ yang berbeda.

To-date

$\mathrm{V}_{1}$ adalah value untuk waktu saat ini (keuntungan yang didapat apabila saham dijual pada harganya yang sekarang), ditambah keuntungankeuntungan lain (dividen, dll). $\mathrm{V}_{0}$ dan I adalah biaya yang telah dikeluarkan dalam rangka melakukan investasi.

To-go

$\mathrm{V}_{1}$ adalah perkiraan harga saham tersebut di suatu masa mendatang. $\mathrm{V}_{0}$ adalah harga beli saham, dan I adalah perkiraan jumlah biaya yang dikeluarkan selama memelihara investasi tersebut. Total ROI

Dengan anggapan bahwa IA memiliki biaya dan keuntungan baik aktual maupun terprediksi, perhitungan $R O I$ jenis lain bisa dilakukan. Sebagai contoh, anda bisa memutuskan akan berinvestasi atau tidak, berdasarkan cukup tidaknya hasil investasi yang dimaksud. Dalam kasus ini, perkirakan hasil perhitungan To-date ROI pada tanggal yang dikehendaki.

\section{Information Economics}

Menurut Ranti (2001), IE adalah teknik analisis/metode yang dikembangkan untuk memberikan manajemen kerangka kerja dari konsep dan alat untuk mengeksplorasi akibat secara ekonomi dari investasi TI dengan menggaris bawahi keuntungan, biaya, dan pemisahan technology justification dari business justification. Metode IE merupakan pengembangan dari metode perhitungan tradisonal, Cost and Benefit Analysis (CBA).

Metode $I E$ ini terakhir dikembangkan oleh Marylin Parker pada tahun 1996. Berikut ini kerangka kerja $I E$ yang didefinisikan oleh Parker (1996):

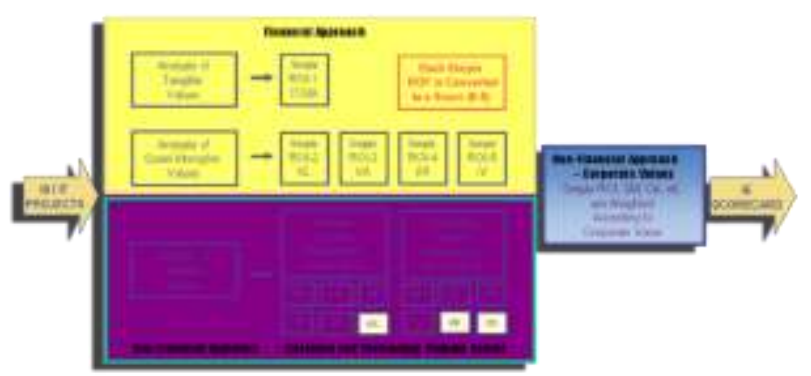

Gambar 1. Information Economics Framework (Sumber : Marylin M.Parker 1996)

Dari gambar di atas dapat dilihat bahwa Parker (1996) menglasifikasikan manfaat yang berpengaruh dalam pengukuran investasi TI ke dalam tiga bagian yaitu:

\section{Tangible Value}

Manfaat nyata atau yang berpengaruh secara langsung terhadap keuntungan perusahaan. Contohnya meningkatkan produktivitas, mengurangi penggunaan kertas, dan sebagainya. Analisis terhadap tangible benefit atau yang bersifat kuantitatif menggunakan perhitungan dengan metode simple ROI- Traditional Cost-Benefit Analysis (TCBA)

\section{Quasi-Tangible Value}

Manfaat yang berada di ruang "abu-abu", atau yang berpengaruh langsung terhadap 
keuntungan tetapi susah dihitung ataupun sebaliknya, tidak berpengaruh secara langsung terhadap keuntungan tetapi dapat dihitung. Contohnya memperbaiki proses perencanaan, perbaikan pengambilan keputusan, dan sebagainya. Analisis terhadap quasi benefit menurut Parker (1996), menggunakan perhitungan dengan:

1. Value Acceleration (VA); percepatan perolehan manfaat dan penghematan biaya karena hubungan dua fungsi dalam hubungan sebab akibat, biasanya dipicu oleh suatu waktu atau perbaikan di bagian lain (ripple effect)

2. Value Linking (VL); sama dengan value acceleration tetapi tidak bergantung pada waktu

3. Value Restructuring (VR); mengacu pada nilai yang berhubungan dengan suatu pekerjaan atau fungsi bagian; diukur dengan peningkatan produktivitas yang didapat dari usaha pada suatu bagian dari aktivitas dengan manfaat yang lebih rendah menjadi meningkat lebih tinggi.

4. Innovation Valuation (IV); aplikasi TI yang inovatif menjadi penggerak dalam perubahan strategi bisnis, produk dan layanan, serta domain bisnis dari organisasi.

\section{Intangible Value}

Manfaat tidak nyata atau yang dapat dilihat mempunyai dampak positif bagi perusahaan, tetapi tidak secara langsung berpengaruh pada keuntungan. Contohnya meningkatkan citra perusahaan, meningkatkan moral pegawai, dan sebagainya. Analisis terhadap intangible benefit menurut Parker (1996) menggunakan dua penilaian yaitu:

\section{a. Business Domain}

Komponen-komponen penilaian dari domain bisnis antara lain:

1. Strategic Match: manfaat teknologi informasi diukur melalui seberapa besar dukungannya terhadap pencapaian tujuan strategis organisasi atau besarnya kontribusi terhadap kegiatankegiatan operasional untuk mecapai tujuan tersebut.

2. Competitive Advantage: manfaat teknologi informasi diukur melalui kontribusinya terhadap pencapaian keuntungan kompetitif organisasi. Penggunaan potensial teknologi informasi adalah untuk menciptakan rintangan persaingan. Dengan demikian, proyek-proyek teknologi yang mendukung sistem antar organisasi (interorganizational system) memiliki manfaat yang lebih tinggi.

3. Management Information Support: kategori ini menilai kontribusi proyek-proyek teknologi informasi terhadap kebutuhan manajemen akan informasi dalam pengambilan keputusan.
4. Competitive Response: manfaat proyekproyek teknologi informasi diukur melalui seberapa besar resiko persaingan jika proyek tersebut tertunda atau tidak dilaksanakan. Semakin proyek tersebut tidak dapat ditunda, maka manfaatnya semakin tinggi.

5. Project or Organizational Risk; berfokus pada resiko jangka pendek yang terkait dengan perancangan ulang proses bisnis dan restrukturisasi organisasional.

\section{b. Technology Domain}

Komponen-komponen penilaian dari domain ini antara lain:

1. Strategic IS Architecture: manfaat proyek SI/TI diukur melalui tingkat kesesuaian proyek tersebut terhadap perencanaan SI/TI secara keseluruhan.

2. Defitional Uncertainty: manfaat proyek SI/TI diukur dari seberapa besar ketidakpastian akibat perubahan dari target

3. Technical Uncertainty: manfaat proyek SI/TI diukur dari seberapa besar ketergantungan proyek terhadap keahlian, perangkat keras, perangkat lunak dan sistem.

4. Infrastructure Risk: manfaat proyek SI/TI diukur dari seberapa pentingnya investasi nonproyek untuk mengakomodasi proyek ini.

Kategori manfaat 1 (tangible) dan 2 (quasi tangible) menggunakan pendekatan finansial enhanced ROI, dimana hasil penilaiannya menghasilkan suatu nilai moneter dan skor angka sedangkan kategori manfaat ke-3 menggunakan pendekatan nonfinansial (domain bisnis dan teknologi), dimana hasil penilaiannya adalah sebuah skor angka. Pada kategori ke-3 ini, skor berkisar dari 0-5 Dengan demikian, menurut Parker (1988), nilai proyek SI/TI diukur dengan formula berikut ini:

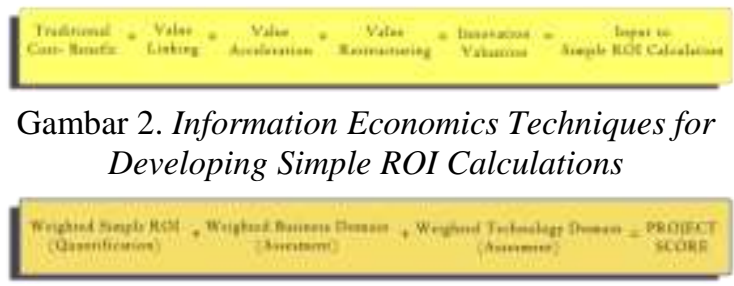

Gambar 3. Factors for computing project score

\section{Metodologi Penelitian}

\section{A. Objek dan Tempat Penelitian}

Penulis mengambil tempat di Jumbo Swalayan Manado Propinsi Sulawesi Utara sebagai lokasi penelitian dan implementasi AutoSell System sebagai objek penelitian. 


\section{B. Bahan dan Alat Perlengkapan}

Bahan dan alat perlengkapan yang digunakan dalam penelitian dan penyusunan tugas akhir ini adalah alat tulis menulis, komputer, printer, kamera digital, jaringan internet dan kalkulator.

\section{Pengumpulan Data}

\section{Observasi}

Metode pengumpulan data yang dilakukan dengan mengamati secara langsung objek yang akan diteliti dan selanjutnya melakukan pencatatan sesuai dengan keperluan.

2. Wawancara

Metode pengumpulan data yang dilakukan dengan mengajukan pertanyaan-pertanyaan, berdasarkan panduan wawancara yang telah disusun.

\section{Kuisioner}

Metode pengumpulan data yang dilakukan dengan cara menanyakan beberapa pertanyaan dengan menggunakan lembar pengisian yang sistematikanya telah disusun sebelumnya.

\section{Studi Pustaka}

Metode pengumpulan data dengan cara mengumpulkan data-data yang berhubungan dengan penelitian dari referensi-referensi berupa literatur, jurnal, buku dan paper riset.

\section{Kerangka Penelitian}

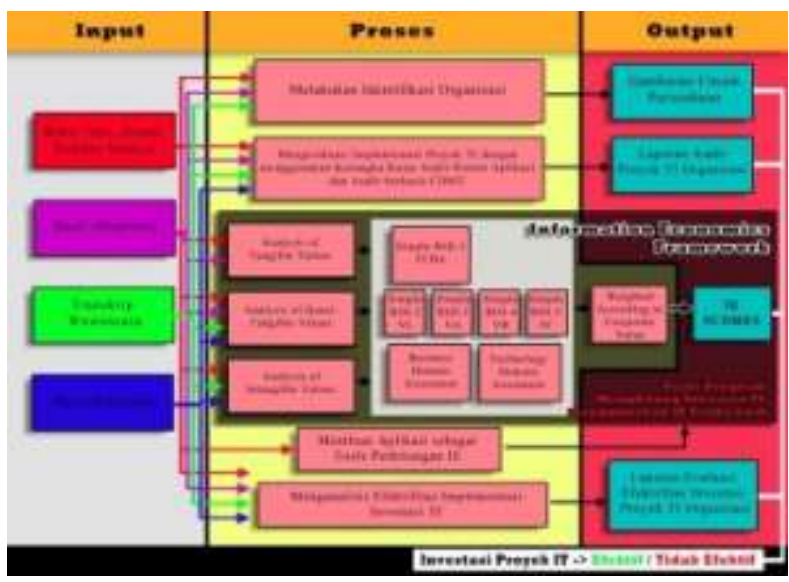

Gambar 4.Kerangka Penelitian Tugas Akhir

\section{E. Gambaran Umum Perusahaan}

Jumbo Swalayan adalah salah satu Perusahaan Retail yang beroperasi di Kota Manado, dan sampai saat ini masih menjadi salah satu swalayan pilihan, ditengah maraknya bisnis serupa yang terus bermunculan di Kota Manado. Sebagai suatu Perusahaan Retail, Jumbo Swalayan adalah Perusahaan milik Keluarga, yaitu Keluarga Bpk Jimmy Lengkong.

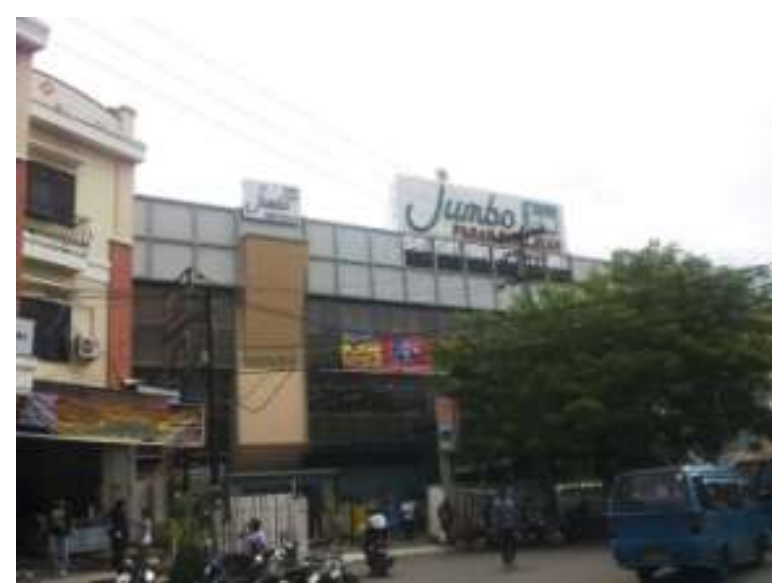

Gambar 5.Jumbo Swalayan Manado

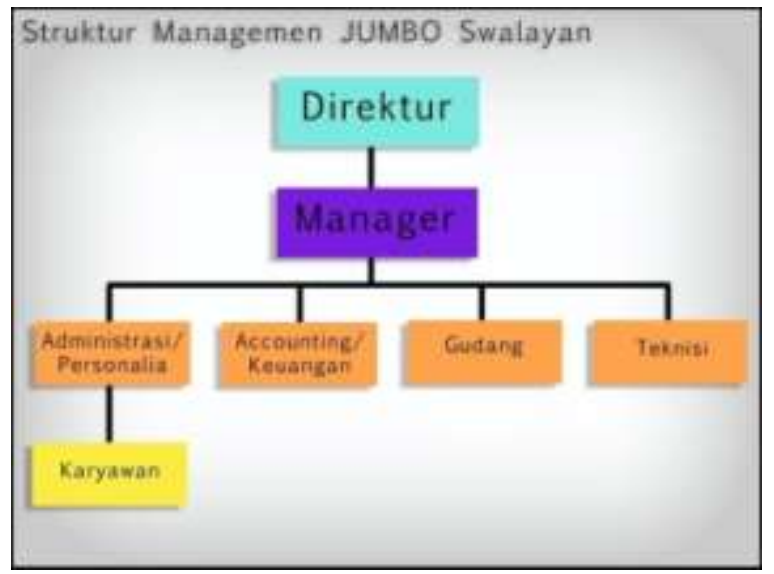

Gambar 6.Struktur Managemen Perusahaan

Pada tahun 2006, pemilik Jumbo Swalayan Manado memutuskan untuk berinvestasi dalam bidang TI, untuk mengubah sistem yang masih diterapkan sebelumya oleh perusahaan. Pemilik perusahaan memutuskan untuk menggunakan AutoSell System, suatu aplikasi kasir yang sudah sering digunakan oleh perusahaan-perushaan retail. Selain pembelian aplikasi, tentunya hal penting lainnya yang juga harus dibeli adalah perangkat komputer dan perangkat keras lainnya untuk menunjang penggunaan sistem tersebut.

Beberapa perangkat yang dibeli adalah Paket Komputer Kasir (Meliputi perangkat komputer kasir, Barcode Scanner dan Bill Printer), PC, Printer, juga perangkat lainnya untuk membangun jaringan intranet perusahaan. 


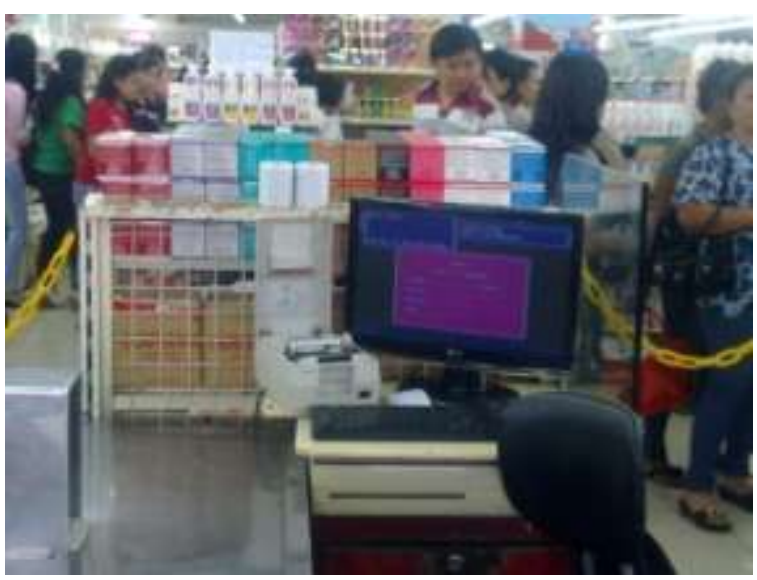

Gambar 7. Implementasi AutoSell System di Jumbo Swalayan Manado

Penggunaan AutoSell System ini tentunya membuat terjadinya perubahan fungsi dalam hubungannya dengan Input Data Barang, Penjualan, dan Perekapitulasian Data Barang yang terjual, dari cara sebelumnya, menjadi terkomputerisasi.

Berikut ini dijabarkan perbandingan Proses Bisnis yang terjadi sebelum dan sesudah pengimplementasian AutoSell System ini:

\section{TABEL 1. PERBANDINGAN PROSES BISNIS SEBELUM DAN SESUDAH MENGGUNAKAN AUTOSELL SYSTEM}

\begin{tabular}{|c|c|c|c|}
\hline $\begin{array}{l}\mathrm{N} \\
\mathrm{O}\end{array}$ & $\begin{array}{l}\text { Proses } \\
\text { Bisnis }\end{array}$ & $\begin{array}{c}\text { Sebelum } \\
\text { mengimplement } \\
\text { asikan AutoSell } \\
\text { System }\end{array}$ & $\begin{array}{c}\text { Sesudah } \\
\text { mengimplement } \\
\text { asikan AutoSell } \\
\text { System }\end{array}$ \\
\hline 1. & $\begin{array}{l}\text { Input Data } \\
\text { Barang }\end{array}$ & $\begin{array}{l}\text { Data barang } \\
\text { direkapitulasi secara } \\
\text { manual } \\
\text { menggunakan } \\
\text { media tertulis. }\end{array}$ & $\begin{array}{l}\text { Data barang di-input } \\
\text { ke dalam database } \\
\text { sistem. Informasi } \\
\text { barang yang di- } \\
\text { input tidak hanya } \\
\text { informasi harga } \\
\text { maupun kode } \\
\text { barang, namun juga } \\
\text { informasi-informasi } \\
\text { lainnya. }\end{array}$ \\
\hline 2. & $\begin{array}{l}\text { Pemberian } \\
\text { Kode } \\
\text { Harga }\end{array}$ & $\begin{array}{l}\text { Kode harga ditulis } \\
\text { manual satu-persatu } \\
\text { pada stiker label } \\
\text { sesuai dengan } \\
\text { informasi harga } \\
\text { barang yang } \\
\text { direkapitulasi } \\
\text { sebelumnya. }\end{array}$ & $\begin{array}{l}\text { Kode barang dicetak } \\
\text { menggunakan } \\
\text { Barcode Printer, } \\
\text { dimana barcode } \\
\text { sticker yang dicetak } \\
\text { telah memuat } \\
\text { informasi barang } \\
\text { sesuai dengan data } \\
\text { yang di-input } \\
\text { sebelumnya ke } \\
\text { dalam database. } \\
\text { Untuk barang yang } \\
\text { telah memiliki } \\
\text { barcode, maka tidak } \\
\text { perlu lagi } \\
\text { menggunakan } \\
\text { barcode sticker. }\end{array}$ \\
\hline 3. & $\begin{array}{l}\text { Pengubaha } \\
\text { n Harga } \\
\text { Barang }\end{array}$ & $\begin{array}{l}\text { Jika terjadi } \\
\text { pengubahan harga } \\
\text { barang, maka harus } \\
\text { dibuat stiker label } \\
\text { yang baru dan } \\
\text { kemudian } \\
\text { mengganti label }\end{array}$ & $\begin{array}{l}\text { Jika terjadi } \\
\text { pengubahan harga } \\
\text { barang, tinggal } \\
\text { mengganti } \\
\text { informasi harga } \\
\text { barang di dalam } \\
\text { database. }\end{array}$ \\
\hline
\end{tabular}

\begin{tabular}{|l|l|l|l|}
\hline & & $\begin{array}{l}\text { harga yang telah } \\
\text { ditempel } \\
\text { sebelumnya dengan } \\
\text { yang baru. }\end{array}$ & \\
\hline 4. & $\begin{array}{l}\text { Pembayara } \\
\text { n di meja } \\
\text { kasir }\end{array}$ & $\begin{array}{l}\text { Barang yang dibeli } \\
\text { akan diinput } \\
\text { harganya } \\
\text { menggunakan mesin } \\
\text { kasir konvensional } \\
\text { (sering disebut } \\
\text { kalkulator besar) }\end{array}$ & $\begin{array}{l}\text { Barang yang dibeli } \\
\text { akan di-scan } \\
\text { barcode yang tertera } \\
\text { pada barang untuk } \\
\text { mengetahui } \\
\text { harganya. }\end{array}$ \\
\hline 5. & $\begin{array}{l}\text { Perekapitul } \\
\text { asian Data } \\
\text { Barang } \\
\text { yang terjual }\end{array}$ & $\begin{array}{l}\text { Data barang yang } \\
\text { terjual direkapitulasi } \\
\text { tiap harinya dengan } \\
\text { mengumpulkan } \\
\text { informasi dari tiap } \\
\text { mesin kasir yang } \\
\text { ada. }\end{array}$ & $\begin{array}{l}\text { Data barang yang } \\
\text { terjual dapat } \\
\text { langsung diketahui } \\
\text { dengan cara } \\
\text { mengakses sistem. }\end{array}$ \\
\hline 6. & $\begin{array}{l}\text { Mengganti } \\
\text { / } \\
\text { menambah } \\
\text { kan stok } \\
\text { barang } \\
\text { yang } \\
\text { dipajang }\end{array}$ & $\begin{array}{l}\text { Karyawan } \\
\text { mengecek secara } \\
\text { berkala setiap } \\
\text { barang yang } \\
\text { dipajang di rak-rak } \\
\text { penjualan, dan jika } \\
\text { sudah habis, akan } \\
\text { menambahkan stok } \\
\text { yang baru. }\end{array}$ & $\begin{array}{l}\text { Administrator } \\
\text { mengecek barang } \\
\text { yang sudah habis } \\
\text { melalui sistem. }\end{array}$ \\
\hline
\end{tabular}

\section{Hasil Pembahasan}

\section{Tangible Values}

TABEL 2.DEVELOPMENT COST WORKSHEET

\begin{tabular}{|c|c|c|c|c|c|c|}
\hline A & \multicolumn{2}{|c|}{ Development Effort } & \multirow{2}{*}{$\frac{\text { Qty }}{4}$} & \multirow{2}{*}{$\frac{\text { Unit }}{\text { Man }}$} & \multirow{2}{*}{$\begin{array}{c}\text { Unit Cost } \\
\text { Rp } 1.000 .000\end{array}$} & \multirow{2}{*}{$\begin{array}{r}\text { Total Cost } \\
\text { Included in } \\
\text { Technician's } \\
\text { salary }\end{array}$} \\
\hline & 1. & $\begin{array}{l}\text { Technician Fee for Physics } \\
\text { Configuration }\end{array}$ & & & & \\
\hline & 2. & $\begin{array}{l}\text { Engineer Fee for PC } \\
\text { Installation }\end{array}$ & 32 & $\begin{array}{l}\text { per- } \\
\text { node }\end{array}$ & Rp 50.000 & Rp 1.600 .000 \\
\hline \multirow[t]{14}{*}{ B } & \multicolumn{2}{|c|}{ New Hardware } & Qty & Unit & Unit Cost & Total Cost \\
\hline & 1. & $\begin{array}{l}\text { PC(Proces sor Intel } \\
\text { Pentium D) }\end{array}$ & 32 & Rss & Kp, 7.000 .000 & Kp 224.000.000 \\
\hline & 2. & $\begin{array}{l}\text { Barcode Scanner } \\
\text { HUNTERS }\end{array}$ & 21 & Pos & Kp 980.000 & Rp. 20.580.000 \\
\hline & 3. & $\begin{array}{l}\text { Barcode PrinterZEBRA- } \\
\text { LINK }\end{array}$ & 1 & Res & $\begin{array}{r}\text { Kp } \\
11.875 .000\end{array}$ & 5.000 \\
\hline & 4. & Bill Printer EPSON & 21 & Pos & Kp 2.400.000 & Rp 50.400 .000 \\
\hline & 5. & UPSPASCAL $450 \mathrm{VA}$ & 25 & Pos & Rp. 1.692 .000 & Rp 42.300 .000 \\
\hline & 6. & RJ-45JACK & 55 & $\mathrm{P}_{S S}$ & Kp 4.000 & Rp. 240.000 \\
\hline & 7. & $\begin{array}{l}\text { LANCable (1 Roll-300 } \\
\text { ft.) }\end{array}$ & 4 & Pos & Kp. 1.020 .000 & Rp. 4.080 .000 \\
\hline & 8. & $\begin{array}{l}\text { Crimping Tool } \\
\text { TRENDNET }\end{array}$ & 3 & Ros & Kp, $\mathbf{2 3 0 . 0 0 0}$ & Kp 690.000 \\
\hline & 9. & $\begin{array}{l}\text { LANCable Testar } \\
\text { TRENDNET }\end{array}$ & 1 & Pos & Kp. 440.000 & Kp. 440.000 \\
\hline & 10. & HUB 3 COM. 24 Port & 6 & Ros & 0.000 & Rp 10.680 .000 \\
\hline & 11. & Printer EPSONFX-1050 & 1 & PSS & Rp. 2.533.000 & $\mathrm{R}_{\mathrm{p}, 2.533 .000}$ \\
\hline & 12. & $\begin{array}{l}\text { Printer Can on PIXMA IP. } \\
1200\end{array}$ & 1 & Pos & Rp 467.000 & Kp. 467.000 \\
\hline & 13. & Printer HPPSC 1210 & 1 & Pos & Kp. 1.415 .000 & Rp. 1.415 .000 \\
\hline \multirow[t]{2}{*}{ C } & \multicolumn{2}{|c|}{ New Purchased Software } & Qty & Unit & Unit Cost & Total Cost \\
\hline & 1. & Auto Sall SystemVer.49 & 1 & Rkg & Rp.5.500.000 & Rp 5.300.000 \\
\hline \multirow[t]{2}{*}{ D } & \multirow{2}{*}{ User 1} & Training & - & - & - & - \\
\hline & & & & & & \\
\hline \multirow[t]{4}{*}{ E } & \multirow{2}{*}{\multicolumn{2}{|c|}{$\begin{array}{l}\text { Other Hardware } \\
\text { 1. Plectrical Plug }\end{array}$}} & Qty & Unit & Unit Cost & Total Cost \\
\hline & & \begin{tabular}{|l} 
Electrical Plug \\
\end{tabular} & 50 & Ros & Kp 5.000 & Kp, 250.000 \\
\hline & 2. & Electrical Cable 10KVA & 300 & Mtx & Rp 15.000 & Kp 4.500 .000 \\
\hline & & & & & TOTAL & $R_{p} 381.550 .000$ \\
\hline
\end{tabular}


TABEL 3.ONGOING EXPENSE WORKSHEET

\begin{tabular}{|c|c|c|}
\hline & & Year1-9 \\
\hline 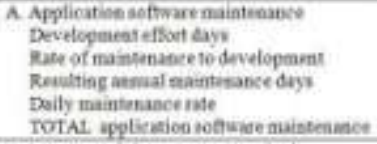 & 6 day & 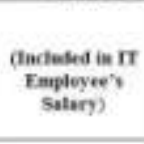 \\
\hline \multicolumn{3}{|l|}{ 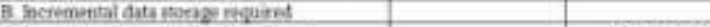 } \\
\hline 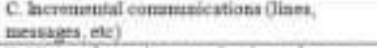 & & Kep 300.000 \\
\hline \multicolumn{3}{|l|}{ D New setware feaeser fardeareleates } \\
\hline \multicolumn{3}{|l|}{ Esarvin } \\
\hline \multicolumn{3}{|l|}{ r. Oteet } \\
\hline 1) II Eerolonet Salury (8 Enployee) & swosty paymest & Fip 120.960 .000 \\
\hline 2) Technician Salary (4 Technician) & Monts puyeret & Re 48.060000 \\
\hline 3) Baecode Mickur & One-yearatock & Be $11,000.000$ \\
\hline 4) Bill Pape & One-year stack & $R_{E} 24.800 .000$ \\
\hline 5) Electrical Cust & Monsty pasment & KE: $24,000.000$ \\
\hline 6) mis Fatill & Mensitypumant & Re 27,090900 \\
\hline Forst & 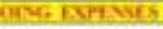 & 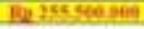 \\
\hline
\end{tabular}

TABEL 4.OPERATING COST REDUCTION

\begin{tabular}{|c|c|c|c|}
\hline Se & $\begin{array}{l}\text { Measuang menekan bien } \\
\text { dari }\end{array}$ & Perhinngan & Tenal \\
\hline$I$ & 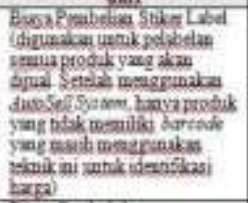 & 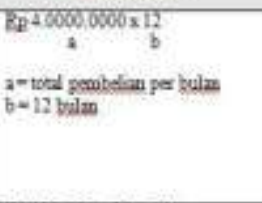 & $\mathrm{K}_{\mathrm{R}}+8,00000$ \\
\hline 2 & 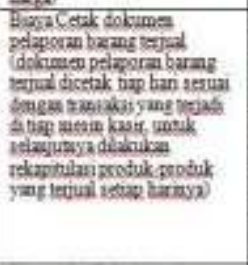 & 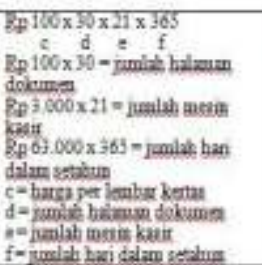 & Bp 22.595.000 \\
\hline 3 & 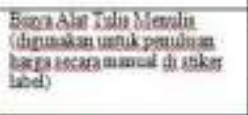 & 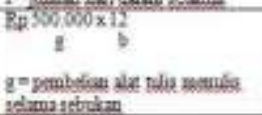 & $R_{R} 6.000 .000$ \\
\hline I. & 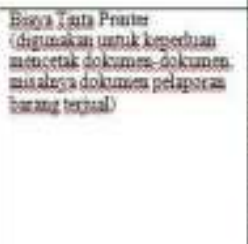 & 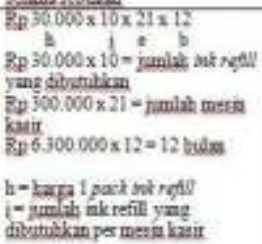 & $\mathrm{K}_{\bar{D}} 75,800.000$ \\
\hline
\end{tabular}

\section{Quasi-Tangible Values}

TABEL 5. NET ECONOMIC BENEFIT - VALUE LINKING

\begin{tabular}{|c|c|c|c|}
\hline $\begin{array}{l}\mathbf{N} \\
\mathbf{0}\end{array}$ & $\begin{array}{c}\text { Mengurangi resiko } \\
\text { dari }\end{array}$ & Perhitungan & Total \\
\hline 1 & $\begin{array}{l}\text { Pengubahan harga } \\
\text { barang secara } \\
\text { manual } \\
\text { (Jika terjadi } \\
\text { pengubahan harga } \\
\text { barang, maka label } \\
\text { stiker di tiap barang } \\
\text { yang ada harus } \\
\text { diganti dengan yang } \\
\text { baru) }\end{array}$ & $\begin{array}{l}\text { Rp 1.200.000 x } 12 \\
\text { a b } \\
\text { a = kisaran pembelian } \\
\text { label stiker yang } \\
\text { diperlukan (30\% dari } \\
\text { pembelian label stiker } \\
\text { wajib bulanan) } \\
\mathrm{b}=12 \text { bulan }\end{array}$ & Rp 14.400.000 \\
\hline 2 & $\begin{array}{l}\text { Kesalahan input } \\
\text { harga barang } \\
\text { (Sering terjadi } \\
\text { dikarenakan harga } \\
\text { barang harus siinput } \\
\text { secara manual oleh } \\
\text { setiap petugas kasir } \\
\text { yang ada) }\end{array}$ & $\begin{array}{l}\text { Rp } 300.000 \times 21 \times 12 \\
\quad \mathrm{c} \quad \mathrm{d} \quad \mathrm{b} \\
\text { Rp } 300.000 \times 21= \\
\text { jumlah kasir } \\
\text { Rp } 6.300 .000 \times 12=12 \\
\text { bulan } \\
\mathrm{c}=\text { prediksi besarnya } \\
\text { kerugian karena } \\
\text { kesalahan penginputan } \\
\text { dalam sebulan } \\
\mathrm{d}=\text { jumlah kasir }\end{array}$ & Rp 75.600.000 \\
\hline 3 & $\begin{array}{l}\text { Kesalahan } \\
\text { Perekapitulasian data } \\
\text { barang yang terjual }\end{array}$ & $\begin{array}{c}\text { Rp } 1.000 .000 \times 12 \\
\mathrm{e}\end{array}$ & Rp 12.000.000 \\
\hline
\end{tabular}

\begin{tabular}{|c|c|c|c|}
\hline & $\begin{array}{l}\text { (Terjadi karena } \\
\text { perekapitulasian } \\
\text { dilakukan secara } \\
\text { manual, setiap } \\
\text { produk yang terjual } \\
\text { harus direkapitulasi } \\
\text { satu persatu) }\end{array}$ & $\begin{array}{l}\mathrm{e}=\text { prediksi besarnya } \\
\text { kerugian karena } \\
\text { kesalahan rekapitulasi } \\
\text { dalam sebulan }\end{array}$ & \\
\hline 4 & $\begin{array}{l}\text { Penipuan / } \\
\text { Kecurangan } \\
\text { Administrasi }\end{array}$ & $\begin{array}{l}\text { Rp } 200.000 \times 25 \times 12 \\
\quad \mathrm{f} \quad \mathrm{g} \quad \mathrm{b} \\
\text { Rp } 200.000 \times 25= \\
\text { jumlah karyawan yang } \\
\text { berhubungan } \\
\text { Rp } 5.000 .000 \times 12=12 \\
\text { bulan } \\
\mathrm{f}=\text { prediksi besarnya } \\
\text { kerugian akibat adanya } \\
\text { penipuan / kecurangan } \\
\text { administrasi } \\
\mathrm{g}=\text { jumlah karyawan } \\
\text { yang berhubungan }(21 \\
\text { petugas kasir }+4 \\
\text { karyawan bidang } \\
\text { administrasi) }\end{array}$ & Rp 60.000.000 \\
\hline 5 & $\begin{array}{l}\text { Kehilangan Data } \\
\text { Barang yang Terjual }\end{array}$ & $\begin{array}{l}\text { Rp } 400.000 \times 25 \times 12 \\
\text { h } \mathrm{g} \quad \mathrm{b} \\
\text { Rp } 400.000 \times 25= \\
\text { jumlah karyawan yang } \\
\text { berhubungan } \\
\text { Rp } 10.000 .000 \times 12= \\
12 \text { bulan } \\
\mathrm{h}=\text { prediksi besarnya } \\
\text { biaya kehilangan data }\end{array}$ & Rp 120.000.000 \\
\hline
\end{tabular}

TABEL 6. NET ECONOMIC BENEFIT - VALUE ACCELERATION

\begin{tabular}{|c|c|c|c|}
\hline $\begin{array}{l}\mathbf{N} \\
\mathbf{0}\end{array}$ & $\begin{array}{c}\text { Keuntungan } \\
\text { yang } \\
\text { dipengaruhi oleh } \\
\text { Waktu }\end{array}$ & Perhitungan & Total \\
\hline 1 & $\begin{array}{l}\text { Kecepatan input } \\
\text { harga barang } \\
=3 \text { detik per } \\
\text { barang } \\
\text { Waktu Operasi } \\
\text { Jumbo Swalayan } \\
=08.00-22.00 \text { (14 } \\
\text { jam per hari) }\end{array}$ & 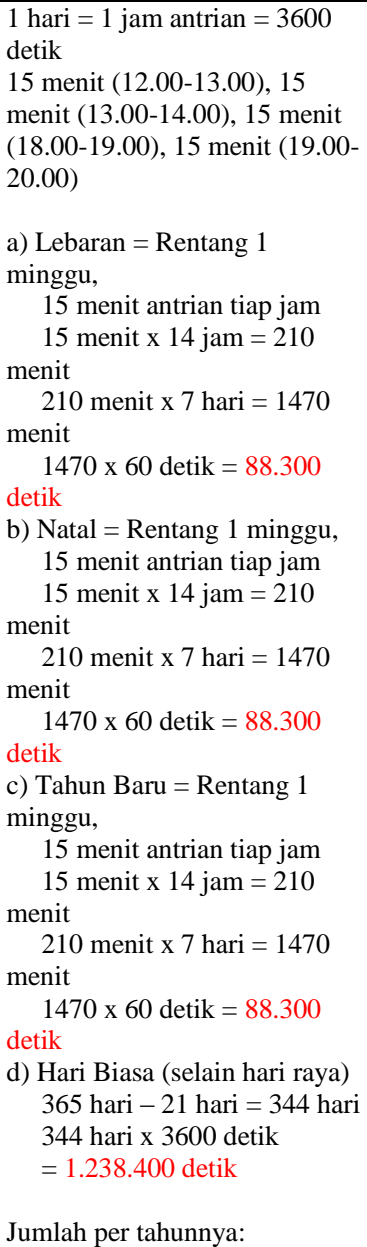 & $\begin{array}{r}\text { Rp } \\
1.503 \\
.000 \\
.000\end{array}$ \\
\hline
\end{tabular}




\begin{tabular}{|l|l|l|}
\hline & $\begin{array}{l}\mathrm{a}+\mathrm{b}+\mathrm{c}+\mathrm{d}=1.503 .000 \text { detik } \\
\text { Jumlah barang yang diproses } \\
\text { dalam rentang waktu tersebut }\end{array}$ & \\
per 1 mesin kasir : & \\
& 1.503 .000 detik $: 3=501.000$ & \\
barang & \\
& 16 mesin kasir & \\
501.000 x 16 = 8.016.000 & \\
& barang & \\
& Harga rata-rata keuntungan & \\
& bersih per barang = Rp 150 & \\
& 8.016.000 barang $\times$ Rp 150 & \\
& $=$ Rp 1.202.400.000 & \\
\hline
\end{tabular}

TABEL 7. PENINGKATAN PROSES KERJA

KARYAWAN - VALUE RESTRUCTURING

\begin{tabular}{|c|c|c|c|c|}
\hline $\begin{array}{l}\mathbf{N} \\
\mathbf{0}\end{array}$ & Divisi & Keterangan & $\begin{array}{l}\text { Sebelum } \\
\text { mengimplemen } \\
\text { tasikan } \\
\text { AutoSell } \\
\text { System } \\
\end{array}$ & $\begin{array}{l}\text { Setelah } \\
\text { mengimplemen } \\
\text { tasikan } \\
\text { AutoSell System }\end{array}$ \\
\hline \multirow[t]{5}{*}{1} & \multirow[t]{5}{*}{$\begin{array}{l}\text { Administr } \\
\text { asi/ } \\
\text { Personalia }\end{array}$} & $\begin{array}{l}\text { Mendata } \\
\text { informasi produk }\end{array}$ & $\begin{array}{l}\text { Informasi } \\
\text { tentang produk } \\
\text { didata secara } \\
\text { manual, tiap ada } \\
\text { produk jenis } \\
\text { baru yang } \\
\text { masuk ke } \\
\text { gudang. }\end{array}$ & $\begin{array}{l}\text { Menginput } \\
\text { informasi data } \\
\text { produk ke dalam } \\
\text { sistem, } \\
\text { informasi yang } \\
\text { diinput lebih } \\
\text { lengkap dan } \\
\text { lebih } \\
\text { terorganisir } \\
\text { dibandingkan } \\
\text { sebelumnya. } \\
\text { Untuk produk } \\
\text { yang disertai } \\
\text { barcode, } \\
\text { barcode tersebut } \\
\text { d-scan untuk } \\
\text { mendapatkan } \\
\text { informasi yang } \\
\text { ada di dalamnya. }\end{array}$ \\
\hline & & \multirow[t]{3}{*}{$\begin{array}{l}\text { Merekapitulasi } \\
\text { produk }\end{array}$} & $\begin{array}{l}\text { Jumlah produk } \\
\text { yang akan di- } \\
\text { display dan } \\
\text { yang masih } \\
\text { tersimpan di } \\
\text { gudang }\end{array}$ & \multirow{3}{*}{$\begin{array}{l}\text { Mengecek } \\
\text { sistem untuk } \\
\text { mengetahui } \\
\text { jumlah produk } \\
\text { yang masih } \\
\text { tersimpan di } \\
\text { gudang, di- } \\
\text { display maupun } \\
\text { yang telah } \\
\text { terjual, untuk } \\
\text { selanjutnya } \\
\text { digunakan } \\
\text { sesuai } \\
\text { kebutuhan }\end{array}$} \\
\hline & & & $\begin{array}{l}\text { direkapitulasi } \\
\text { (dengan bantuan } \\
\text { karyawan) }\end{array}$ & \\
\hline & & & $\begin{array}{l}\text { Mengumpulkan } \\
\text { data produk } \\
\text { yang terjual dari } \\
\text { tiap meja kasir, } \\
\text { yang } \\
\text { direkapitulasi } \\
\text { setiap harinya. }\end{array}$ & \\
\hline & & $\begin{array}{l}\text { Membuat } \\
\text { Barcode }\end{array}$ & $\begin{array}{l}\text { Mendata tiap } \\
\text { harga produk } \\
\text { yang ada untuk } \\
\text { selanjutnya } \\
\text { ditindak lanjuti } \\
\text { oleh karyawan }\end{array}$ & $\begin{array}{l}\text { Mencetak } \\
\text { barcode produk } \\
\text { menggunakan } \\
\text { barcode printer } \\
\text { untuk } \\
\text { selanjutnya } \\
\text { ditindak lanjuti } \\
\text { oleh karyawan } \\
\end{array}$ \\
\hline \multirow[t]{2}{*}{2} & \multirow[t]{2}{*}{ Karyawan } & $\begin{array}{l}\text { Membuat / } \\
\text { Memasang } \\
\text { Barcode }\end{array}$ & $\begin{array}{l}\text { Menuliskan } \\
\text { harga barcode } \\
\text { menggunakan } \\
\text { media barcode } \\
\text { stiker untuk } \\
\text { selanjutnya } \\
\text { ditempelkan ke } \\
\text { semua produk } \\
\text { yang ada. }\end{array}$ & $\begin{array}{l}\text { Menggunakan } \\
\text { barcode yang } \\
\text { telah di-print } \\
\text { untuk } \\
\text { selanjutnya } \\
\text { ditempelkan ke } \\
\text { produk yang } \\
\text { belum memiliki } \\
\text { barcode. }\end{array}$ \\
\hline & & Kasir & $\begin{array}{l}\text { Mengetik harga } \\
\text { produk untuk } \\
\text { selanjutnya } \\
\text { dikalkulasi }\end{array}$ & $\begin{array}{l}\text { Men-scan harga } \\
\text { produk } \\
\text { menggunakan } \\
\text { barcode scanner } \\
\text { untuk } \\
\text { selanjutnya }\end{array}$ \\
\hline
\end{tabular}

\begin{tabular}{|c|c|c|c|c|}
\hline & & & & dikalkulasi \\
\hline 3 & $\begin{array}{l}\text { Accountin } \\
\text { g/ } \\
\text { Keuangan }\end{array}$ & $\begin{array}{l}\text { Merekapitulasi } \\
\text { pemasukan }\end{array}$ & $\begin{array}{l}\text { Merekapitulasi } \\
\text { pemasukan } \\
\text { setiap harinya } \\
\text { sesuai dengan } \\
\text { data rekapitulasi } \\
\text { dari bagian } \\
\text { administrasi }\end{array}$ & $\begin{array}{l}\text { Mengecek } \\
\text { sistem untuk } \\
\text { mengetahui } \\
\text { pemasukan yang } \\
\text { ada. }\end{array}$ \\
\hline 4 & Gudang & $\begin{array}{l}\text { Mengatur } \\
\text { penyimpanan } \\
\text { produk }\end{array}$ & $\begin{array}{l}\text { Mendata setiap } \\
\text { produk yang } \\
\text { masuk dan } \\
\text { keluar dari } \\
\text { gudang } \\
\text { penyimpanan } \\
\text { dengan cara } \\
\text { mengecek } \\
\text { secara langsung }\end{array}$ & $\begin{array}{l}\text { Mendata setiap } \\
\text { produk yang } \\
\text { masuk dan } \\
\text { keluar dari } \\
\text { gudang } \\
\text { penyimpanan } \\
\text { dengan cara } \\
\text { mengecek secara } \\
\text { langsung dan } \\
\text { menggunakan } \\
\text { sistem untuk } \\
\text { mengetahui } \\
\text { informasi } \\
\text { jumlah produk } \\
\text { yang masih ada } \\
\text { maupun telah } \\
\text { out of stock }\end{array}$ \\
\hline 5 & Teknisi & $\begin{array}{l}\text { Maintenance } \\
\text { infrastruktur }\end{array}$ & & $\begin{array}{l}\text { Memeriksa dan } \\
\text { juga } \\
\text { memperbaiki } \\
\text { keseluruhan } \\
\text { infrastruktur dari } \\
\text { AutoSell System } \\
\text { yang telah } \\
\text { diimplementasik } \\
\text { an. }\end{array}$ \\
\hline
\end{tabular}

Setelah mengidentifikasi tiap Value pada Tangible dan Quasi-Tangible, selanjutnya menghitung Economic Impact Worksheet. Dapat dilihat bahwa nilai Net Economic Benefit mengalami pelonjakan, menjadi Rp 1.484.400.000 per tahunnya. Total Net Cash Flow yang diperoleh Rp 6.907.475.000, artinya semenjak mengimplementasikan AutoSell System, perusahaan mengalami penaikan keuntungan sebesar di atas dalam kurun waktu 5 tahun. Keuntungan tersebut di luar pendapatan Perusahaan dari penjualanpenjualan produk yang biasanya. Skor Simple ROI untuk proyek yaitu 2 dengan nilai $\mathbf{3 6 2 \%}$

A. Net Investment Required $=R p 381.550 .000($ From Development Cost Worksheet)

B. Yearly Cash Flow

TABEL 8.ECONOMIC IMPACT WORKSHEET

\begin{tabular}{|c|c|c|c|c|c|c|}
\hline & \multicolumn{5}{|c|}{ YEARS } & \multirow{2}{*}{$\begin{array}{c}\text { TOTA } \\
\mathrm{L} \\
\end{array}$} \\
\hline & 1 & 2 & 3 & 4 & 5 & \\
\hline Net & & & $\mathrm{Rp}$ & $\mathrm{Rp}$ & $\mathrm{Rp}$ & \\
\hline Econ & 1.484 .4 & 1.484 .4 & 1.484 .4 & 1.484 .4 & 1.484 .4 & \\
\hline omic & 00.000 & 00.000 & 00.000 & 00.000 & 00.000 & \\
\hline \multicolumn{7}{|l|}{$\begin{array}{l}\text { Bene } \\
\text { fit }\end{array}$} \\
\hline Oper & $\mathrm{Rp}$ & $\mathrm{Rp}$ & $\mathrm{Rp}$ & $\mathrm{Rp}$ & $\mathrm{Rp}$ & \\
\hline ating & 152.59 & 152.59 & 152.59 & 152.59 & 152.59 & \\
\hline Cost & 5.000 & 5.000 & 5.000 & 5.000 & 5.000 & \\
\hline \multirow{2}{*}{\multicolumn{7}{|c|}{$\begin{array}{l}\text { Redu } \\
\text { ction }\end{array}$}} \\
\hline & & & & & & \\
\hline$(=)$ & & $\mathrm{Rp}$ & $\mathrm{Rp}$ & $\mathrm{Rp}$ & $\mathrm{Rp}$ & $\mathrm{Rp}$ \\
\hline Pre- & 1.636 .9 & 1.636 .9 & 1.636 .9 & 1.636 .9 & 1.636 .9 & 8.184 .9 \\
\hline $\operatorname{tax}$ & 95.000 & 95.000 & 95.000 & 95.000 & 95.000 & 75.000 \\
\hline \multicolumn{7}{|l|}{$\begin{array}{l}\text { Inco } \\
\text { me }\end{array}$} \\
\hline$(-)$ & $\mathrm{Rp}$ & $\mathrm{Rp}$ & $\mathrm{Rp}$ & $\mathrm{Rp}$ & $\mathrm{Rp}$ & $\mathrm{Rp}$ \\
\hline On- & 255.50 & 255.50 & 255.50 & 255.50 & 255.50 & 1.277 .5 \\
\hline going & 0.000 & 0.000 & 0.000 & 0.000 & 0.000 & 00.000 \\
\hline expe & & & & & & \\
\hline $\begin{array}{l}\text { nse } \\
\text { from }\end{array}$ & & & & & & \\
\hline Work & & & & & & \\
\hline
\end{tabular}




\begin{tabular}{|l|r|r|r|r|r|r|}
\hline sheet & & & & & & \\
\hline$(=)$ & $\mathrm{Rp}$ & $\mathrm{Rp}$ & $\mathrm{Rp}$ & $\mathrm{Rp}$ & $\mathrm{Rp}$ & $\mathrm{Rp}$ \\
Net & 1.381 .4 & 1.381 .4 & 1.381 .4 & 1.381 .4 & 1.381 .4 & 6.907 .4 \\
cash & 95.000 & 95.000 & 95.000 & 95.000 & 95.000 & 75.000 \\
flow & & & & & & \\
\hline
\end{tabular}

C. Enhanched Return on Investment

Return on Investment $=(\operatorname{Rp} 6.907 .475 .000 / 5 / \operatorname{Rp} 381.550 .000)$

$=3.620744332=362 \%$

TABEL 9.SCORING ECONOMIC IMPACT

\begin{tabular}{|c|c|}
\hline Score & Simple ROI \\
\hline 0 & Zero or less \\
\hline 1 & $1 \%$ to $299 \%$ \\
\hline 2 & $\mathbf{3 0 0 \%}$ to $499 \%$ \\
\hline 3 & $500 \%$ to $699 \%$ \\
\hline 4 & $700 \%$ to $899 \%$ \\
\hline 5 & over \\
\hline
\end{tabular}

\section{Intangible Values}

1. Business Domain Assesment

1. Strategic Match

Skor 4 untuk Strategic Match yang menunjukkan bahwa proyek memberikan pengaruh secara langsung (sesuai dengan kapasitasnya) untuk pencapaian tujuan strategis dari perusahaan.

2. Competitive Advantage

Skor 3 untuk Competitive Advantage yang menunjukkan bahwa proyek menyediakan beberapa fasilitas untuk akses dari luar juga pertukaran data, dan menaikkan nilai kompetitif perusahaan, namun tidak signifikan.

3. Management Information Support

Skor 4 untuk Management Information Support yang menunjukkan bahwa proyek memberikan kontribusi untuk menyediakan Management Information for Critical Success Factors (MICSA) di masa mendatang.

4. Competitive Response

Skor 4 untuk Competitive Response yang menunjukkan bahwa penundaan proyek ini akan berakibat pada kerugian kompetitif bagi perusahaan; atau kehilangan kesempatan kompetitifnya; atau kegiatan-kegiatan yang telah berlangsung sebelumnya di perusahaan akan mengalami degradasi karena tidak dibangunnya sistem yang dimaksud.

\section{Project or Organizational Risk}

Skor 3 untuk Project or Organizational Risk yang menunjukkan bahwa domain bisnis organisasi tidak memiliki rencana yang memadai untuk mengimplementasikan sistem (ditandai dengan tidak adanya pembagian tugas yang jelas, tidak adanya prosedur kelengkapan berkas penunjang yang memadai, dan lain sebagainya), sehingga terjadi berbagai kendala ke depannya di beberapa sisi, yang memiliki pengaruh pada sistem.

\section{Technology Domain Assesment}

\section{Strategic IS Architecture}

Skor 3 untuk Strategic IS Architecture yang menunjukkan bahwa proyek yang dibangun merupakan bagian penting dari perencanaan strategi dengan pembiayaan, bukan prasyarat untuk perencanaan investasi lain yang terdapat dalam perencanaan strategis SI perusahaan, namun terhubung dengan prasyarat investasi lainnya.

2. Definitional Uncertainty

Skor 1 untuk Definitional Uncertainty yang menunjukkan bahwa persyaratan untuk proyek cukup jelas, spesifikasi cukup jelas. Tidak ada persetujuan formal. Area telah jelas. Memiliki probabilitas perubahan non-rutin yang rendah.

\section{Technical Uncertainty}

Skor 2 untuk Technical Uncertainty yang menunjukkan:

1. Beberapa ketrampilan baru dibutuhkan untuk para karyawan

2. Hardware belum tersedia di perusahaan sehingga harus diadakan

3. Software yang digunakan standar, tidak diperlukan kemampuan programming

4. Program telah tersedia secara komersial dengan modifikasi minimal saja (jika diperlukan).

\section{IS Infrastructure Risk}

Skor 4 untuk IS Infrastructure Risk yang menunjukkan bahwa beberapa perubahan pada layanan pengiriman komputer diperlukan, pada beberapa area. Penginvestasian pada hardware, software dan karyawan diperlukan untuk mengakomodir proyek. Investasi ini tidak termasuk dalam pengeluaran langsung, namun lebih merujuk pada investasi fasilitas SI untuk membentuk lingkungan proyek yang diperlukan.

\section{Corporate Value}

Dari hasil observasi di Jumbo Swalayan Manado, hasil wawancara dan juga menjalankan kuisioner kepada karyawan bagian administrasi / personalia dan yang menangani aplikasi AutoSell System, berikut ini pemaparan tentang kekuatan Line of Business dan Computer Support dari perusahaan:

Line of Business: Weak

1. Tidak ada rencana jangka panjang / pendek terkait pengembangan TI untuk perusahaan

2. Tidak ada perencanaan TI yang menjelaskan tentang urutan prioritas proyek dari yang tertinggi sampai terendah

3. Tidak ada manager / pengawas yang secara langsung menangani bagian TI dan berkompeten di bidang TI

4. Tidak ada karyawan di perusahaan yang memiliki latar pendidikan TI maupun Ilmu Komputer

Computer Support : Weak

1. Sistem yang digunakan sering mengalami hang sehingga harus berjalan dalam mode offline.

2. Aplikasi kasir yang digunakan tergolong produk lama, masih kalah bersaing 
dibandingkan dengan aplikasi kasir di perusahaan lain dalam hal fungsi, kecepatan, juga efisiensi kerja.

3. Aplikasi masih berjalan dalam mode $D O S$

4. Tidak ada kegiatan pemantauan secara berkala untuk tiap infrastruktur and akses fisik yang berhubungan dengan sistem.

Dengan memperhatikan kedua faktor di atas, maka dapat ditarik kesimpulan bahwa Corporate Value dari Jumbo Swalayan Manado menggunakan Infrastucture Quadrant, dimana quadrant tersebut memiliki cirri-ciri Line of Business lemah dan Computer Support lemah.

Berikut ini adalah penjelasan bobot IE Score untuk Infrastructure Quadrant Corporate Value.

\section{TABEL 10.INFRASTRUCTURE QUADRANT} CORPORATE VALUE

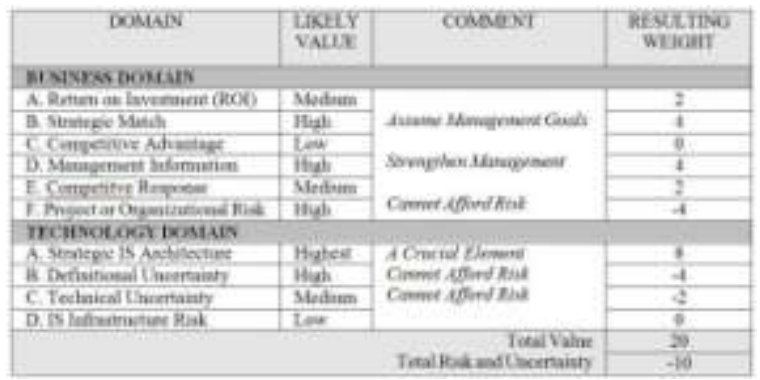

\section{Information Economics Scorecard}

Tahap akhir, memasukkan setiap skor yang telah didapat ke dalam IE Scorecard. Untuk Skor dari ROI, yang digunakan adalah skor final dari Enhanched ROI yang didapat berdasarkan akumulasi dari Tangible Value dan beberapa nilai dari QuasiTangible Value. Selanjutnya untuk skor dari Intangible Value dalam hal ini dari domain bisnis dan domain teknolgi, menggunakan skor yang telah didapat berdasarkan penjabaran pada bagian Intangible Value di atas.

Setiap skor yang didapat akan dikalikan dengan pembobotan menggunakan Infrastructure Quadrant Corporate Value.

Berikut ini adalah IE Scorecard untuk AutoSell System dari Jumbo Swalayan Manado.
TABEL 11. INFORMATION ECONOMICS SCORECARD

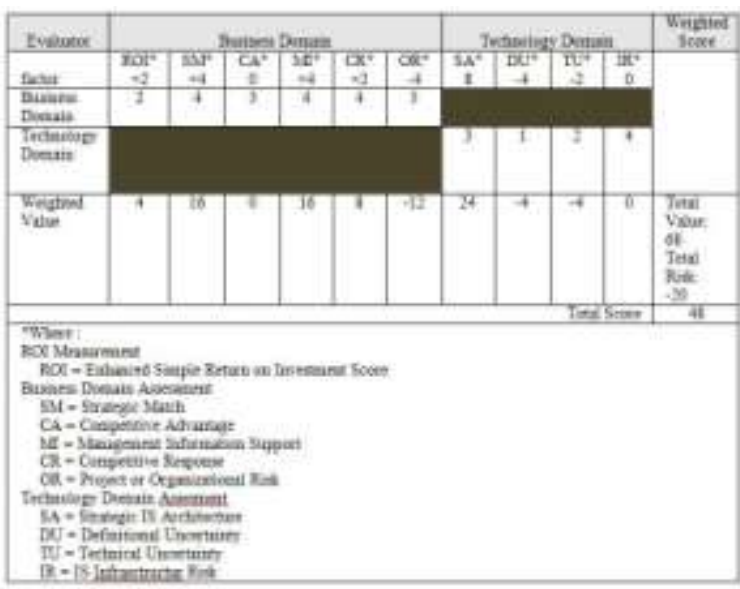

Selanjutnya, skor yang didapat akan ditinjau berdasarkan lima kelas ukuran dalam tabel predikat proyek, yaitu Sangat Kurang, Kurang, Cukup, Baik, dan Sangat Baik. Ukuran tersebut dirancang dengan memperhatikan skor tertinggi dan terendah dari penilaian $I E$ dengan menggunakan pembobotan Infrastructure Quadrant Corporate Value. Dan hasilnya adalah sebagai berikut:

TABEL 12.PREDIKAT PROYEK

\begin{tabular}{|c|c|}
\hline Skor & Predikat \\
\hline $71-100$ & Sangat Baik \\
\hline $\mathbf{4 1 - 7 0}$ & Baik \\
\hline $11-40$ & Cukup \\
\hline$(-21)-10$ & Kurang \\
\hline$(-50)-(-20)$ & Sangat Kurang \\
\hline
\end{tabular}

Skor akhir dari investasi AutoSell System di Jumbo Swalayan Manado bernilai 48. Jika dilihat dari Tabel di atas, dapat diketahui bahwa investasi AutoSell System ini mendapat predikat "Baik" yang berarti penerapan teknologi informasi menggunakan AutoSell System ini dinilai cukup baik dan bermanfaat bagi Jumbo Swalayan Manado. Dengan menggunakan metode Information Economics diketahui bahwa nilai ROI mencapai $362 \%$ dan $I E$ Score masuk dalam kategori "Baik" (Total skor 48). Keuntungan yang didapat dalam kurun waktu 5 tahun sebesar 6.907.475.000

\section{Information Economics Tools}

IE tools dirancang untuk membantu dalam menghitung tiap nilai yang didapat dengan menggunakan metode $I E$. Aplikasi ini dibuat dengan tujuan untuk mempercepat proses perhitungan.

Aplikasi ini dibuat dengan menggunakan bahasa pemrograman Java, dan dirancang dengan menggunakan Eclipse, salah satu IDE (Integrated Development Environment) yang men-support penggunaan Java. Spesifikasi minimal yang diperlukan adalah: 
1. Software

: Java Development Kit (JDK) Ver.7

2. Sistem Operasi : Windows XP, Vista, 7

3. Processor $: 1 \mathrm{GHz}$

4. RAM :256MB

5. HDD : $124 \mathrm{MB}$

Berikut ini adalah tampilan dari IE Tools tersebut:

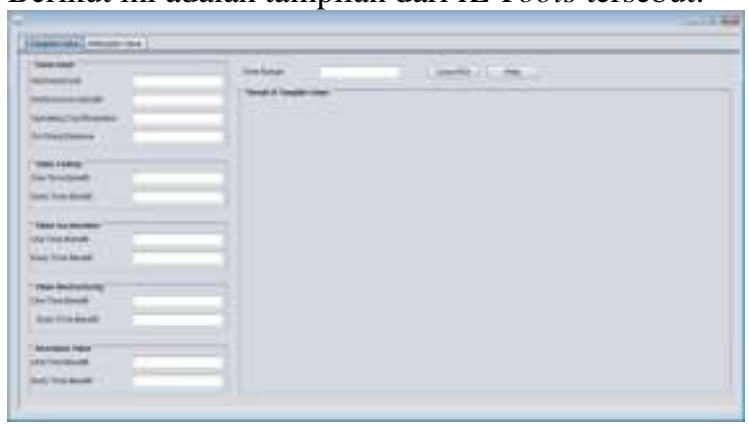

Gambar 8. Tampilan IE Tools (Tangible Value)

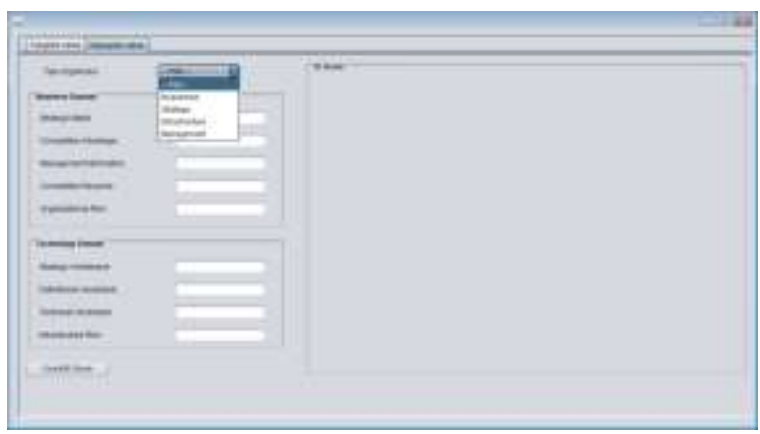

Gambar 9. Tampilan IE Tools (Intangible Value)

Untuk memasukkan nilai, dapat dilakukan persis seperti pada langkah perhitungan $I E$, diawali dengan memasukkan nilai-nilai Tangible Value, Quasi-Tangible Value, dan terakhir Intangible Value.

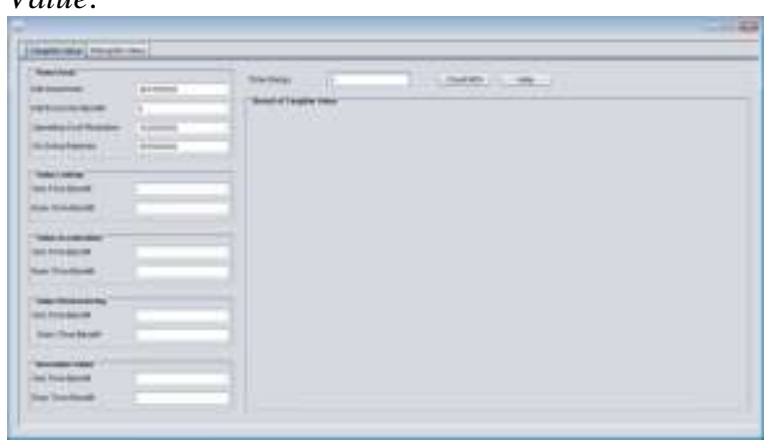

Gambar 10. Langkah pertama (memasukkan nilai Tangible Value)

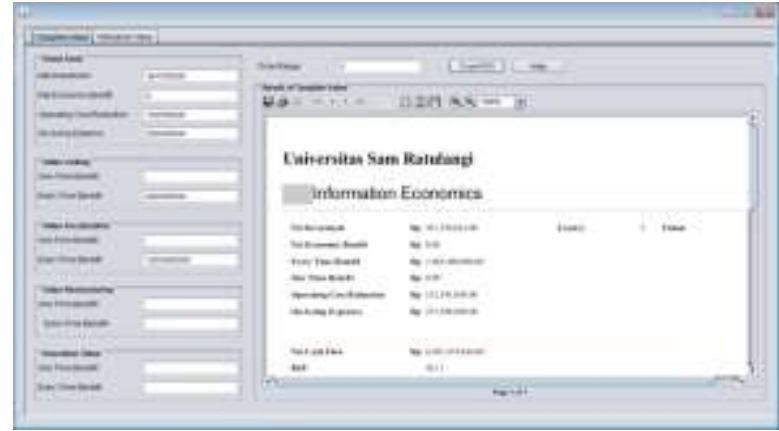

Gambar 11. Langkah kedua (memasukkan nilai Quasi-Tangible Value)

Pada kolom Intangible Value, harus dipilih 1 dari 4 kategori Corporate Value yang ada, selanjutnya masukkan tiap skor, dan selanjutnya nilai dapat diproses untuk memperoleh IE Score.

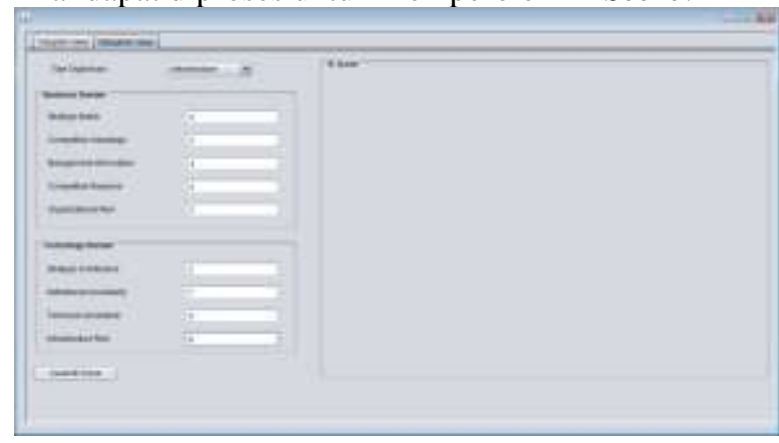

Gambar 12. Langkah ketiga (memasukkan nilai Intangible Value)

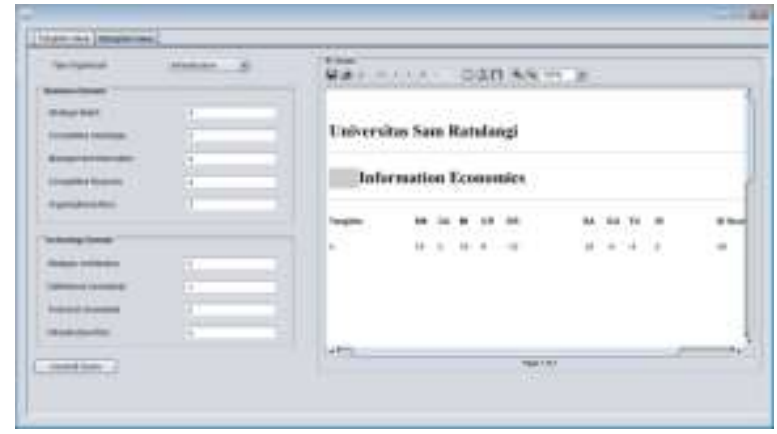

Gambar 13. Hasil akhir perhitungan (IE Score)

\section{Kesimpulan}

1. Implementasi AutoSell System secara keseluruhan dinilai efektif bagi perusahaan. Dengan menggunakan metode Information Economics diketahui bahwa nilai ROI mencapai $362 \%$ dan IE Score masuk dalam kategori "Baik" (Total skor 48). Keuntungan yang didapat dalam kurun waktu 5 tahun sebesar 6.907.475.000

2. Penggunaan aplikasi kasir seperti AutoSell System di Jumbo Swalayan Manado terbukti merupakan kebutuhan mutlak bagi perusahaan yang bergerak di bidang retail; untuk meningkatkan performa perusahaan dan 
menaikkan nilai kompetitif perusahaan itu sendiri.

3. Berdasarkan hasil evaluasi implementasi AutoSell System dengan menggunakan kerangka kerja Audit, ditemukan bahwa masih ada kekurangan-kekurangan yang terdapat pada sistem; sistem dapat mengalami hang, tidak ada fitur backup data, dan lain sebagainya, yang sangat mempengaruhi performa sistem secara keseluruhan, dan dibutuhkan langkahlangkah pengendalian strategis kedepannya untuk meminimalisir resiko-resiko tersebut. Selain itu ditemukan bahwa ketiadaan Manager maupun karyawan yang berkompetensi di bidang TI di perusahaan sangat mempengaruhi kualitas kerja dari karyawan-karyawan yang mengoperasikan sistem tersebut.

4. Implementasi AutoSell System meningkatkan performa bisnis perusahaan dari berbagai aspek dilihat dari sisi efisiensi dan efektifitas, namun banyak kelemahan yang ditemukan dari segi perencanaan TI yang berpengaruh kedepannya dalam rangka pengembangan TI perusahaan itu sendiri.

\section{DAFTAR PUSTAKA}

[1] C. Murray, Calculate your Return on Investment for Software and Systems. IBM. 2012

[2] F. Edmund, Planning and Implementing IT Portfolio Management: Maximizing the Return on Information Technology Investments. 2005

[3] H. Henny, Analisis Efektifitas Investasi Aplikasi Oracle menggunakan Metode Information Economics PT ITCF. Penerbit Piranti Warta. 2008

[4] K. Stenly, Contoh Implementasi Audit TI dengan Kerangka Kerja CObIT. Manado. 2011

[5] P. Marilyn, Information Economics: Linking Business Performance to Information Technology. Englewood Cliffs. New Jersey. 1996

[6] R. Benny, Managing IT Investment. University of Indonesia. 2001

[7] R. Benny \& K. Stenly. Applying Information Economics and IT Valuation Matrix. University of Indonesia. 2011

[8] W. Arianto, Merencanakan Penelitian Information Economics. 2008

[9] Yanti, Keputusan Investasi Teknologi Informasi. Binus Journal. Jakarta Barat. 2008

[10] Yulia, Kajian Kelayakan Investasi Proyek Teknologi Informasi dengan Menggunakan Metode Information Economics. Universitas Kristen Petra. 2010 